\begin{tabular}{|c|c|}
\hline $\begin{array}{l}\text { ÇÜTAD } \\
\text { Çukurova Üniversitesi } \\
\text { Türkoloji Araștırmaları Dergisi }\end{array}$ & $\begin{array}{c}\text { Cilt 5, Sayı } 1 \\
\text { Haziran } 2020\end{array}$ \\
\hline $\begin{array}{l}\text { ISSN: 2587-1900 } \\
\text { E-ISSN: 2548-0979 }\end{array}$ & 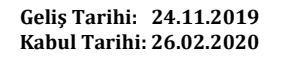 \\
\hline \multicolumn{2}{|c|}{$\begin{array}{l}\text { Makale Künyesi (Çeviri): Maşkaraoğlu, S. (Çev.) (2020). Tatar şair } \\
\text { Zölfet ve şiir sanatı: sık ormanda bülbül öter. Çukurova Üniversites } \\
\text { Türkoloji Araştırmaları Dergisi. } 5 \text { (1), 194-209. }\end{array}$} \\
\hline
\end{tabular}

\title{
TATAR ŞAİRİ ZÖLFET VE ŞIIIR SANATI: SIK ORMANDA BÜLBÜL ÖTER ${ }^{1}$
}

\section{ÖZET}

Seher MAŞKARAOĞLU ${ }^{2}$

Çağdaş Tatar şiirinin önde gelen temsilcisi Zölfet (Dölfet Gosman oğlu Malikov) Sovyet dönemi özgürlük sıkıntılarına rağmen eserlerinde kullandığı cesur ve lirik dille çağdaş edebiyatta özel bir yer tutmaktadır. Altmış yaşında vefat eden şair, Abdullah Tukay adına konan Devlet ödülünün sahibidir ve 2007 yılında Tatar edebiyatına katkıları dolayısıyla devlet madalyasıyla ödüllendirilmiştir. Zölfet'in şiirleri her zaman geniş halk kitleleri tarafindan sevilerek okunmuştur. Şair, "Ikě Urman Arasında" kitabının girișinde yer alan "Çıtırmanda Bılbıl Sayrıy..." başlıklı ön sözünde şiir sanatı hakkındaki düşüncelerini okuyucularına açıklamıştır. Burada Tatar şiir sanatını savaş, kahramanlık ve propaganda şiiri olmaktan çıkarmayı amaçladığını belirterek şiiri "gönül sesini cihana ulaştırmak için bir araç” olarak gördüğünü söylemiştir. Bu çalışmada, Tatar şiirine büyük katkısı olan şair Zölfet'in hayatı ve edebi faaliyetleri hakkında kısa bilgi ve şairin şiir sanatı hakkındaki düşüncelerini açıkladığ “Çıtırmanda Bılbıl Sayrıy..." başlıklı yazısı yer alacaktır.

Anahtar kelimeler: Zölfet, Tatar şiiri, şiir sanatı.

\section{TATAR POET ZÖLFET AND HIS POETICS: NIGHTINGALE SINGS IN THE DENSE FOREST}

\begin{abstract}
Zölfet, a prominent representative of contemporary Tatar poetry, occupies a special place in contemporary literature with the bold and lyrical language he used in his works despite the problems of freedom during the Soviet era. He is the recipient of the State Prize for the poet Abdullah Tukay, who passed away at the age of sixty, and was awarded a state medal in 2007 for his contribution to Tatar literature. Zölfet's poems have always been read and loved by the masses. The
\end{abstract}

\footnotetext{
${ }^{1}$ Bu çalışma, Prof. Dr. Mustafa Öner danıșmanlığında hazırlanıp 2012 yılında savunulan "Tatar Şairi Zölfet'in Şiirleri Üzerine Bir Dil İncelemesi (Giriş, Metin, Dizin)" başlıklı yüksek lisans tezinden üretilmiştir.

${ }^{2}$ Kilis 7 Aralık Üniversitesi, Fen-Edebiyat Fakültesi, Türk Dili ve Edebiyatı Bölümü, Dr. Öğr. Üyesi. seher.maskaraoglu@kilis.edu.tr https://orcid.org/0000-0003-2448-724X
} 
poet explained his thoughts about the art of poetry to his readers in his preliminary statement titled "Çıtırmanda Bılbıl Sayrıy" in the introduction of the book "Ikě Urman Arasinda". He stated that Tatar aims to remove the art of poetry from war, heroism and propaganda and he said that he saw the poem as a means of conveying the heartfelt voice to the world. In this study, brief information about the life and literary activities of the poet Zölfet, who made a great contribution to Tatar poetry, and his commentary on the art of poetry "Çıtırmanda Bılbıl Sayriy..." will take place.

Keywords: Zölfet, Tatar poetry, poetics.

\section{YAŞAM ÖYKÜSÜ VE EDEBÎ FAALIYYETLERİ}

Dölfet Malikov 3 Ocak 1947 tarihinde Tataristan ASSR'nin Möslim bölgesi Yaña Seyět köyünde çiftçi bir ailede dünyaya gelir. Ortaokulu tamamlayınca, 1965-1969 yıllarında Kazan Devlet Üniversitesi'nin Filoloji Fakültesi Tatar Dili ve Edebiyatı bölümünde okur. 1969 yılında gazetecilik hizmetine "Çayan” dergisi yazı işleri idaresinde edebî memur olarak başlar, ardından Moskova'nın M. Gorkiy isimli edebiyat enstitüsünün iki yıllık yüksek edebî kurslarını tamamlayarak "Yeş Leninçı" gazetesinde yayıncı olur. 1983 yılından ömrünün son günlerine kadar "Çayan” dergisinde çalışır (Zölfet, 2007, s. 192).

Zölfet'in ilk şiirleri daha öğrencilik yıllarında ortaya çıkar. Şairin "Yazmışlar Yarında" isimli ilk kitabı 1971 yılında Hesen Tufan'ın giriş sözü ile yayımlanır. Edebi tenkit ilk yayınlarından itibaren şairin aydınlık karakterini, şiirlerinin olgun biçimini ve lirizmini belirler (Zölfet, 2007, s. 192).

Zölfet'in daha sonraki sanatı, çok sayıda poetik eseri, vatandaşlık ve lirik şiirleri, manzumeleri, baladları, "Utlı Bozlar", "Adaşkan Bolıt", "İkě Urman Arası", Yöregěmně Bılbıl Çaktı" ve diğer kitaplarında toplanarak geniş halk kitleleri tarafından sevilip kabul edilir (Zölfet, 2007, s. 192).

1985 yılında Tataristan kitap neşriyatında şairin Rusça tercümeyle "Osenniye kostrı" isimli kitabı ve Moskova'nın "Sovremennik" neşriyatında 1988 yılında "Sozvezdiye Süyümbeki" adında kitabı basilır (Davutov, 1986, s. 193).

Dünya edebiyatı klasiklerinden W. Shakespeare ve F. Schiller'in piyesleri de Zölfet'in Tatarca çevirileriyle sahnelenir (Öner, 2008, s. 50).

Zölfet halkın gönlüne giren güzel türkülerin de yazarıdır. $O$, gerçekten halkın sevdiği bir şairdir. Tatar halkının kaderi, geçmişi, 
bugünü ve geleceği edebiyatçının sanatında esas yeri almaktadır. Zölfet'in şiir sanatı milyonlarca okuyucusunu derinden etkileyip onların yüreğine girmiştir (Zölfet, 2007, s. 192).

Poetik düşünceyi yayarak göstermeye çalışmak, halka karışmak, temsilcilik, etkili ve orijinal tasvir gücü, düzenli ritim Zölfet'in tarzına has özellikleridir (Türkiye Dışındaki Türk Edebiyatları Antolojisi-19, 2001, s. 440).

\section{BASILMIŞ KITTAPLARI}

Yazmışlar Yarında: şigırler / kěrěş süz avt. H. Tufan. - Kazan: Tatar. kit. neşr., 1971.

Utlı Bozlar: şigırler. - Kazan: Tatar. kit. neşr., 1978.

Adaşkan Bolıt: şigırler, poemalar, balladalar. - Kazan: Tatar. kit. neşr., 1990.

İkě Urman Arası: ěssě, şigırler, cırlar, poemalar. Kazan: Tatar. kit. neşr., 1995. 1999.

Yöregěmne Bılbıl Çaktı: şigırler, poemalar. - Kazan: Ruhiyat,

Hoday Sulışı: şigırler. - Kazan: Tatar. kit. neşr., 2007.

Osenniye kostrı: stihodvoreniya / per. s Tatar. M. Akçurina. Kazan: Tatar kn. pzd-vo, 1985.

Sozvezdiye Süyümbike: stihi sovremennıh Tatarskihpoetov. - M.: Sovremennik, 1988.

\section{ŞIIIRLERINDDEKI BAŞLICA KONULAR}

Tatar edebiyatında büyük yankılar uyandıran Zölfet, lirik şiirin öncülerindendir. Şiiri "hayat yolu"na benzeten şair, bu yolu Tatar tarihi, coğrafyası ve kimliği ile var etmiş, bunu yaparken "Her şiirin aslı samimiliktir" diyerek, şiiri salt belâgatin elinden kurtarmış, samimiliğiyle bezemiştir.

Zölfet'in şiiri kendi ifadesine göre "Gönül sesini cihana ulaştırmak için bir araç”tır. Bu yüzden bu sesi bulmak için sözün kendisine önem verir. Onun şiirleri Tatar şiir sanatını, "savaş şiiri”, "kahramanlık şiiri”, epik unsurlarla örülü propaganda şiiri olmaktan çıkarmayı amaçlar. 1995 basımı "İkě Urman Arası" başlıklı kitabının girişinde şiir sanatı hakkında söz ederken şiiri âdeta bir dua kabul etmektedir (Zölfet, 1995, s. 21). 
Tatar halkını sadece kahraman bir halk olarak görmeyip kahramanlığının yanı sıra duygusallığının da farkında olan şair, şiirlerinde bu ikisinin sentezini yapar. Savaşları ve hatta savaşlarda yer alan atları, tarihsel olayları, bu tarihsel süreçteki sıradan insanları konu alan şair, bunun yanında bu sıradan insanların gündelik dertlerini de dile getirir. Tarihsel şahsiyetler, dervişler, evliyalar da onun şiirinde yerini alır. Şiirini yaşamın tam ortasında var eden Zölfet, doğadan da hiçbir zaman kopmaz.

Doğa onun şiirinde pastoral bir öge olmanın ötesinde, mecazların da hayat bulduğu bir yerdir: Bülbüller, kartallar, guguk kuşları bu şiirlerde metafor olarak kullanılır. Bu kelimelerin anlamları toplumsal zemine taşınır.

Şair gibi şiirin de beslendiği toprak bir zemin olduğunu düşünen Zölfet, bu zemine Tatar türkülerini, danslarını, şiirlerini, resimlerini yerleştirir. Şiirini kendi kimliğini var eden ögelerden besler. Bu söylemi şiirini söz yığını olmaktan kurtarır.

Zölfet, bir halkın çektiği acıları, yaşadığı zorlukları, öz kimliğini kaybetmeme çabasını içinde taşımaktadır. Şiiri adeta onun bu kederinin dışavurumudur. Dolayısıyla bunu olabildiğince derinden duyurmaya çalışır. Tarihin sadece anayasalardan değil, şiirlerden de okunması gerektiğini düşünen şair, bu nedenle tarihin bulanık aynasının ardındaki sırrı, okuyucuya aksettirmeye çalışır.

\section{SIK ORMANDA BÜLBÜL ÖTER ${ }^{3}$}

Benim yazdıklarımı az çok bilenler hatırlarlar belki "Tatar", "Millet", "Özgürlük" gibi sözleri değil meydanlara çıkıp bağırmak, kendi aramızda bile konuşmanın yasak olduğu günlerde ben "Çakırılmagan kunak - Tatardan da yamanrak..." (Çağrılmayan konuk - Tatardan daha da kötü) başlıklı bir şiir yazmıştım. Şiir akşamlarında olsun, şiir severlerle geçirilen görüşmelerde olsun, bu eserim salonda oturanlara bomba patlamış gibi güçlü etki ediyordu, onları ayıltıp sıçratıveriyordu. Bugün ise kalem oynatabilen herhangi biri bu konu hakkında yazıyor. Fakat ne kadar üzücü ki bu gibi eserleri okumak da dinlemek de bugün nedense keyifsiz olmaya başladı. Niye böyle peki? Hikmet nerede? Faydalı olanı ne kadar yazsan da faydalı olmamakta $\mathrm{m} 1$ ?

"Mehebbet" adındaki eserim de bu devirlerde denildiği gibi, gençliğimin şafağında yazılmıştı. $\mathrm{O}$, ne hakkındaydı? Bu şekilde,

\footnotetext{
${ }^{3}$ Metnin özgün künyesi: Zölfet (1995). Çıtırmanda Bılbıl Sayrıy. İkě Urman Arası, Kazan: Tatarstan Kitap Neşriyatı, 7-22.
} 
sadece dışarıdan baksan ayıya teke tek karşı çıkacak derecede, onu bıçakla yıkabilecek kadar gayretli bir erkeğin, karşılıksız aşktan yıpranıp sonsuz azaplarını da içkiyle bile bastıramayınca çektiği acılar hakkındaydı. Dur! Sadece bu konuda mıymış ki? Öyleyse niçin bizim zihnimizde şekillenip tamamlanmış bir ifade ile söylersek, hayatta kendi yerini bulamamış bir "sarhoş" hakkındaki eser "üst düzey komünist ideallerin çiçek açtığı" bir devirde meşhur söz ustası Ayrat Arslanov'un repertuvarından uzun yıllar boyunca düşmeden yaşaya geldi ve aynı zamanda, beni gösterişle suçlamayınız, dinleyiciler onu dinledi? (Aslında, devrin bir özelliği olarak, anmadan geçilmez, içkiye karşı mücadele başlayınca Ayrat ağabey o şiiri okumadı). Hatırlıyorum, şair Nebi Devli yıllık şiir hakkındaki bildirisinde, işte bu şiirimi de göz önünde tutup "Zölfet çağdaşlarının portrelerinden galeri kurar" demişti. Millet, neden şimdiye kadar ben bunlardan söz ediyorum?

Kendi hatıralarımı yenilemek için mi sadece? Gurur mu? Ya da ben buna bugün muhtaç mıyım? Hayır, hiç de öyle değil, zaman kaygısı benim genel olarak şiir hakkındaki düşüncelerimi kendinde bir tertibe koymaya itti, bugüne kadar çıkmaya yol bulamadan gönlümde sızlayıp duran sıkıntılarımı haykırmaya imkân verdi, hatta mecbur etti.

Söylemeye çalışayım bir...

Her asil şiirin kendi tarihi var.

Gönül tarihinden mahrum şair coğrafyadan, tarihten mahrum devlettir. Sınırları, bitki örtüsü, canlıları, atmosferi yani soluyacak nefesi de olmayan devlet... Onun üstünden zaman rüzgârı esmez. O, doğduğunda ölür. Onun gibi devlet olmaz, olamaz da...

Fakat ne yaparsın, işte böyle gönül tarihinden mahrum şiir sanatını hatırlatan dizeler sayısız.

Şiir, hayat yoludur. Anketlerde, otobiyografilerde ne kadar istersen, o kadar birbirini aldatırsın. Gerçek şair ise, çok istese de, başkalarını, özellikle kendini aldatamaz. Aldatacak hilesi varsa, o büyük yalan yutturmacı yani şiir derecesine çıkıp böylesine şiirlere benzer yazmayı bilen belâgatli yetenek sahibidir. Her şiirin aslı, samimiliktir. Doğru sestir. Doğru ezgidir.

Bizde iki türlü sapma var. Birisi şiir tatsız sözlerin daha şı, daha sert yankılanmasındadır diye inanmak. İkincisi şiir gücü, sözlerin mümkün olduğu kadar zavallı yankılanışında, ağlatmasında diye inanmak. 
Peki, ocağın, ateşin gözüne girip bakmışlığın var mı? Kendin, kazıp bulduğun kaynak dibindeki kıpırdanıp duran aydınlık, serin kirpiklere dudak değdirip baktın mı? Yıldızların sessiz hareketinden başının döndüğü zamanlar oldu mu? Sabahki çiy tanesinin içinden sana sevdiğin yârin firlayıp bakmadı mı?

Eğer gerçekten de benim söylediklerim senin tabiatında da varsa, oku dostum şiirini! Saklayıp durma! Senin şiir yazdığını ben zaten biliyorum. Gizlercesine yazsan da, bizim ortak sözümüz var. Bazen şöyle de olur: Gelirler ve yüreğe girer gibi yapıp gözlerini dikerek derin manalı bakıp dururlar... Ve koynundan altın dolu kese çıkarmış gibi şöyle derler: "Güzel şiirlik tema vereyim ben sana! Yaz! Telifi ortak olur!”

- Ey, kardeş! diye zorlanıp oflarım ben bunun gibi zamanlarda. Kendi temalarımı yazıp bitirmek için de Tanrıdan sağlıklı ömür isterdim. Fakat gücüm yetmiyor. $\mathrm{O}$ ise inanmıyor.

Ama gönülde sızı kalır, insanoğlu ömrü boyunca söylemek isteyip de söyleyemeden 1stırap çekince bana, şair insana müracaat etti herhâlde. Aslında, biz cihana işte şu sözleri, gönül seslerini ulaştırmak için doğmuşuzdur... Kadersiz şiir yok diyorlar. Sadece öyle miymiş? Tatarın büyüğü Gabdelcabbar Kandalıy ${ }^{4}$ olgusunu nereye koyuyorsunuz? Onun hayat yolunu âlimler de yaklaşı olarak bilir. Oysa şiirlerinden ben onun her soluğunu duyarım. Demokrat molla. İçindeki dışında olan ateşli, özgür ruhlu kişi. "Hayyamlığı" taşıp duruyor. Kişisel mutluluğu, elbette yok. Son eşi şairin kendinden kalan şiirlerini sağa sola dağıtıp israf ederek bitirmiş. Şiir sıkıntısından ölen bu kişinin kaderini anlatacak sözler var mı? Ne zahmet şu, şiir? Söylemeye çalışayım mı?

Şiir, bana kalsa, uçup duran cihan toz bulutundan aranarak bulunabilip olgun bir düzene konulan, hiçbir şeyin bozamayacağ ritme bağlanmış biricik ahenge boyun eğdirilmiş Mecusi, ateşli sözler yankısıdır.

Aslında, her şair bunu kendince anlatabilirdi. Gerçek şiiri var eden her harf tapınmaya layık. Daha insanoğlu yaşayışının sabahında pek çok sopayla baş yarmayı öğrenivermiş. Ama bu vahşiler arasında şafağın çizgi hâlinde sökmesine şaşırıp hayran olarak bakıp duran, şu

\footnotetext{
${ }^{4}$ Gabdelcabbar Kandalıy, yeni devir Tatar nazmının en meşhur şairlerindendir. Güçlü şiir yeteneği, eserlerinin sanatça nefis yapımı, dilinin sadeliği, kendi döneminin ciddi meselelerini aydınlanma fikri temelinde ele alması ile Tatar edebiyatında önemli bir yer tutmaktadır (Türkiye Dışındaki Türk Edebiyatları Antolojisi-19, 2001).
} 
güzelliği anlatmaya çabalayanlar da olmuş şüphesiz! Tam da bu insan, insanlığın ilk şairidir... Ne oldu acaba sonra onlar? İlk söz, ilk ezgi, ilk suret, ilk fikir... Vallahi söyleyeyim, şunları sadece bir işitmek, görmek, duymak için bile ruhumu İblise satardım.

Ama bu büyük sırrı anlatmaya insanoğlunun gücü yetmez. Yazarlığı biz izafi isimle belirlemişiz, Allahü Teala. Bu Allah karşısında iman edermiş gibi şiir yazalım, sadece iman şartını değil, şiir şartını da bilelim, dünyadan imansız gitmekten korktuğumuz gibi şiirsiz gitmekten de korkalım! Kötü kişi hakkında "İmansız!" diyerek değil, "Şiirsiz!" diyerek hüküm çıkarmak gerektir... Bir baktığında komik olarak algılansa da, bu değerde düşünüp bakmak hiçbirimize zarar vermez. Allahü Teala eksiksiz ve sonsuz ritme razı olan Kaos değil miymiş? Dünyanın yüreği tam işte şu kesintisiz çarpıp nefes nefese kalarak duran Kaos muymuş peki? Görünce bu ahmağı, şiirin nasıl olduğunu anlatmaya çalışırım değil mi?

Dünyada bundan daha da manasız iş yoktur. Ama yine de kişi niye sözleri ezgiye yerleştiriyor peki? Basitçe: “Al!”, "Ver!” diye söylemek yetmemiş mi ki? Tabiat insanoğluna seslerin ve renklerin en olgun imkânına da yol açmış. Halk her zaman olgun söze saldırır. Duvarlardaki utanmaz yazılar, suretler, basit şiirler işte bu isteğin yorumu sonucu. Demek ki, bu tarafta Tanrı'ya kolay sözü, rengi, sesi eriştirir gibi kişiler kalmamış... Ya da onları işitmek istemezler. Kulaklarımızı İblis tıkamış.

İlginç bir fikir var: Dünyanın gerçek kişileri dâhiler, diğerleri gerçek kişi değil. Değildir. Asil şiir sanatından yüz çeviren toplumda suçlular çoğalır, yoksullar artar.

Bülbülün midesi hangi kısımlardan oluşur? Onun soluk alıp verdiren diyaframı nerede? Kim bilir nerelere kadar işitilen saf sesini ortaya çıkaran yerleri, sinir uçları nerede onun? Bilmiyorum ve bilmek de istemiyorum. Su kıyısındaki sabah sögüdünün dibine yat ve dinle... Fazlası gerekli değil. Fazlasını bilsem, sıradan biyolojik yapı olurdum. Olur da, şiirin ne zaman yazılacağını tasarlasam, hiçbir yere de çıkmadan sadece evde otururdum. Ama şiiri nasıl yazmak gerektiğini de bilsem, Tukay'ı sessiz bırakacak şiirleri cilt cilt yazıp atardım. Onun gibi şiirleri bilmem ve ben bununla mutluyum.

Tabiatın kendisini hiç kimsenin giremeyeceği şekilde kapatarak kilitleyip bıraktığı afetli bölgeye, seslerin dolaşmasına, cesurca atılıp ben yapayalnızım gidip gireyim. Sözle göz göze kalırım. Yakalanırım. Alın alına gelirim. Nihayet ben ona boyun eğdiririm, Kaos'tan alıveririm, sadece kendimin bildiği ezgiye sindiririm. Ömürlük düşmanım olan kudretli sözü kendimin ömürlük dostu ederim. En 
sevilmeyen sorularım: "Şiir nasıl yazılır? En sevilen şiiriniz hangisi? Bu şiir ne hakkında?" Peki, öyleyse anlatınız bana: Tan nasıl gözükür? En sevilen tanınız hangisi? Tan ne hakkında? Samimi söz yavaşça, göze bakarak söylenir.

Sevgi hakkında meydanlara çıkıp bağırmazlar. Sıradan söz ne zaman şiire dönüşür? Bunu bana sürü güden dede basitçe anlattı. "Çakı, bıçak da değdirme! Elinle de dokunma! Ama işte bu çubuğun sapını kısalt!, dedi. Düşüne düşüne tamamen deliye dönmeye başladım, ah! Merhamet etmiş olsa gerek, dede kıpırdayarak gülüverdi ve:"

- Sırrı çok basit onun evlat, dedi. Tersini değil, tersten düşünmeyi öğren... Ve o senin uzun çubuk sapını benim daha kısa çubuk sapımın yanına koydu da:

- Tamam mi, kısaldı mı?, dedi.

Ama biz daima sap kısaltırız, diye, hep bükülüp balta vururuz.

Övünüp durduk: "Tatar şiir sanatı, asker şiiri! Bizim şiirimiz, savaşçıların şiiri! Savaşçılar gerek!”. Ama Tatar geçmişinden gelen lanetli yazgısı hakkında içinden kederlenip bu şekilde diyerek sızlanmış:

Sik orman... Karanlık gece...

Güzel atlar gerek elbette geçmeye...

Devir zor... Yollar kapalı!

Eş dost gerek dünyada kalmaya...

Koloni kurucusunun çorap yerine koyup bastığı halkın yazgısı hakkında yazılması gerekli binlerce kitapta bulunur bu dört yol. Tatar tarihini anlatmak için bütün sözler aransa boş. Tatar şiir sanatı, lanetli kader sanatıdır. Gerisi, yalandır.

"Yollar kapalı!" bizim kaderimizin damgası işte bu. Bunu ilk kez kim, nerede söyledi acaba? Darbe vurulan halk işte bu türküye tutuna tutuna bugüne kadar gelivermiş. Bu türküyü unutan gençlerimiz neye tutunur? Başaklı yemliğe baş sokup homurdanmayı bırakan, yıldızlara göz atan her domuz, şair. Savaşa çağırmak, vahşilik. Savaş; saldırmak, öldürmek, tecavüz etmek, yıkmak, alay etmek, kırmak. Savaş, vahşilik işi. Onun maksadı, zafer. Zafer, iğrenilecek tören. Gerçek şiir duaya denktir. Onun diğer abdestsiz sözlerden farkı işte bundadır. Gerçek sözler şair diline tutulmayı bekleyip acı çeker. Dünyayı anlamaya değil anlatmaya çalışmak, şairin yok olması. 
Şöhret, alkış için yazmak günah. Kendi şairlerini para için şiir yazmaya mecbur eden toplum iki kat fazla günahkâr. Çünkü o Tanrı'nın sadece kendisinin yarattı̆̆ı kuluna verdiği nadir hediyeyi, özelliği şahsi menfaatleri için kullanır. Tanrı sözünü yalvararak değil, satarak alır. Benim şiirimi okuyunca, kızla erkek öpüşüyorsa, hayatımın anlamı var demektir. Benim şiirimi okuduktan sonra biri diğerinin boğazını kesip kan akıtıyorsa ben cehennem parçasıyım.

Efkârlanınca, sözler şiire dönüşmeye başladı.

Kavurur ülkeyi sıcak rüzgâr

Bağırarak, uğuldayarak, yükselerek...

Çıkarım ateşten tenhalara.

Ben, karanlık bir bulut.

Başarır ve gider sıcak rüzgâr...

Bedduası göğe bakarak:

- Alıştı elbette bu!,

Gitmese, işler harap...

Yine de ben yürürüm... Damla toplarım

Sarılıp yağmak için

Son kez nemi bekleyen dudağa

Ayrılıp damlamak için!

Yürürüm başucunuzda

Açılmaz bir sır olup

Allah değil,

Resul değil,

Ben,

Karanlık bir bulut

(Karanlık Bulut)

Ve şimdi sadece söylediklerimi karalarken gözümün önüne dâhi Kul Gali'nin kaderi gelir.

...Ben eski dudakları öperim.

Yaşayışım! Köklerin derin!

Kan atışım

Sicak dalga olur

Yükselir ebediyen donmuş yerden.

Katmanlara derin indikçe,

Göklere değer başım. 
Tanrı'nın yaşadığı yükseklikten

Sevgili yeryüzü derin canını öperim.

Tan sizliyor

Uzak köklerde.

Giyindiğim zırh

Gökyüzüm, tepem

...Son sefer öncesinde kılıç biliyorum.

Ve eski dudakları öpüyorum.

Bugünkü devir ise şaire kılıç tutturmuş, onun aydınlık hayallerinden parlayan başını Moabit'te ${ }^{5}$ kesmiş, Kolıma'da ${ }^{6}$ çürütmüş. Fakat eski zamandaki bir büyük hükümdar hakkında şöyle bir iyi vaka korunup kalmış. Sözde, savaşa girmeden önce o şöyle bir ferman vermiş:

- Şairleri ve eşekleri ortada bırakınız! Onlar savaştan sonra gerekli olacak! Bunun tersi: Arap büyük savaşçılarından birisi savaş öncesi şöyle ferman vermiş:

- Bu sıcakkanlı, hayali delikanlıları, şairleri sefere önce sokunuz! Diğer askerleri teşvik etsinler!

Gençliğimde, Musa Celil hakkında düşüncelere dalıp, şu şekilde yazmıştım:

\section{...Savaşabilen bülbül o}

Ve ötebilen kartal...

Bülbülünü savaş kartalı yerine düşman üstüne yürümeye mecbur eden ülkenin, halkın günahlarını kim çoğaltır?

Edebiyatımızın kanını kurutan bir kötü düşünce bugün de hâkimiyete ulaşabildiği için sadece "popüler" yazar olup keyif sefa süren beyefendileri himaye eder. O düşünce, "Halkçılık". Halkın o vekili alıp satıp zengin olmuş, paradan bitlenmiş bir Tatar tiyatroya gelince ne yapıyordu? Kabarıp oturduktan sonra perde açılmayınca bu "halk vekili" kıpırdanmaya başlamış:

- Başlayacaksanız başlayın. Başlamayacaksanız, ne yapıyorsanız yapın, bırakır ve giderim!

\footnotetext{
${ }^{5}$ İkinci Dünya Savaşı yıllarında Tatar şairi Musa Celil ve 12 arkadaşının tutuklu kaldığı Alman toplama kampı.

${ }^{6}$ Stalin döneminde zorunlu çalışma kamplarına ev sahipliği yapan, Rus Uzak Doğu'sunda bulunan bir coğrafi ve tarihi bölgedir.
} 
Ama oyun başlayınca büfeden "içki içip" giren de o:

- Gülesim geliyor! Artistler gelin buraya! Gıdıklayın beni!, diyerek bütün tiyatroya bağırıp oturmuş.

Peki, halkçı oldum diye, bu oburun karnını gıdıklamak için mi yazayım şimdi? Nice yıllar boyunca sanatımızı şu "Prokrust yată̆ı" ${ }^{7}{ }^{7}$ dayandırıp diri tenine canına kıydık. Güçlü sanata layık olması için halk kendi "Halk" derecesine çıkarılsın!

Sibgat Hekim'in bir sözü aklımda kalmış: “Türkünün türkü olması için üçünün; şair, besteci, türkücünün birbiriyle mutlaka kesişmesi gerek". Yeryüzü, su, gökyüzü birliği değil mi peki bu? Şiirin yıldızı gökyüzü olmak zorunda değil, kurbağalı sazlık olsa da çok şükür, sadece canlı olarak görsen! Bana pek çok demeç hazırlamak nasip oldu. İlk "oyun" bugün de göz önünde duruyor. Demeç hazırlayıcı şairler kitaplarını, not defterlerini karıştıra karıştıra "daha etkili" şiirler ararlar: "Bu salonda bu geçer, bu kulübe böylesi de olur... Gerekli mi soylular için! Anlamayacaklar!”. Müzisyenler ise halkı ağlatıp alkışlatanları, "Annem bağrım" teması etrafında aramaya girişirler. Böyle olunca zevkimizin aşağıya yuvarlanmasından kim suçlu? Bugünkü Tatar'ın fikir yürütüşü mitingdeki megafon derecesine düşmüşken, bunun için kimin cevap vermesi gerek? Bilmiyorum, ama bugünkü şiir sanatının, sonunda, kendi yüksekliğinden bakarak yankılanmaya başlaması gerek. Eğilip de, diz çöküp de değil! İşitmiyorsan, anlamıyorsan, yalaktan başını kaldırıp yükselerek bak! Semiz boynun uykudan kalkmak istemiyorsa bundan sadece sen suçlusun kardeş! Bülbülün mutluluğu, ötmekte. Onun faciası da ötmekte, bülbülün yüreğini kavurup yemek Roma imparatorları için şöhret, zenginlik, bolluk işareti olarak sanılmış. Oysa bizim halkımız iki yürek olmadan, geleceğe sağlıklı, huzurlu varamaz. Birinci yürek kahraman yüreği, ikinci yürek bülbül yüreği. Ancak kirpinin mutluluğu, tenhada. Ceviz çalısı dibindeki sessiz yerde.

Gençlik çağlarımda ben sağanak yağmur yağınca büyük dulavrat otu yaprağı altına girip sık, yeşil yaprağa şap şup gelen damla şıpırtılarını dinlemeyi çok istedim.

\footnotetext{
${ }^{7}$ Prokrust, Yunan mitolojisinde bir yolkesen, soyguncudur. Atina'ya giden yollardaki seyyahları, yolcuları şirin dille kandırıp evine götürür. Evinde biri kısa biri uzun iki demir yatağı vardır. Kandırdığı insanların kısa boylu olanlarını uzun yatağa, uzun boylu olanlarını ise kısa yatağa bağlar. Kısa boylu olanlarını mengene ile gererek, uzun boylu olanların fazlalıklarını keserek boylarını yatağa uygun hâle getirir.
} 
İnanıyorum, kendini fazla havalı gören şairler sabahleyin güneş 1şıklarının buğusunun çıkardığı boşlukta yeşilliğin zorlana zorlana filiz vermesini duymuyorlardır da. Çünkü onların kulak frekans aralığı fazla yüksek. Şiir; bulutun, güneşin, toprağın karışımı, sıradan yeşillik. Bu yeşilliğe koyu çiy düşünce ayakların bembeyaz olup ağarıncaya kadar, saf, serin, parlayıp duran çiyleri sıçrata sıçrata koş ve koş! Ve de bunun keyfini sadece sözlerle başkalarına anlatıver. O serin çiy başkalarının da tabanını ısıtsın.

Müslümanlık yanlısı kişilerin ağız doldurarak küfredebilmesine şaşırıyorlar. Yumuşak, nazlı, hassas dil... Müslüman kişi hatta kendine sövüp saymayı da insanın başına gelmez gibi lirizme, manzum eserlere gizleyebilir. Elden ne gelir, hiç de söylenmezlerdi, devir buna layık. Söyleniyorsan, dilin de temiz kalsın, insanı üzüp bitirme, söylediğini de duygulara dalarak söyle. Buna çok benzer hâle Polonya'da rastladım. Polonyalılar sokakta kendileriyle konuşup gide gide, öfkesi gidince, tam da bize tanıdık “...Şah! Mat!”a geçerler.

Neden böyle? Birisi kendi dilini kirlilikten korumaya gayret ediyordur belki... Ancak sadece kendi dilini en üstün, en yüce olarak ispat etmeye gayret eden her milletin kaderi acıklı. Büyük eserler meydana getirmede sadece yetenekli dil yüce. İnsanlığın en büyük dâhisi, en önemli dil uzmanı ilk kez aya bakan da, hayran olduğundan "Ay!" diye şaşırıp kalmış. Bugüne kadar "ay" demişiz. Dünyanın insanoğlunun görmeye başladığı her nesnesine isim veren kişi, elbette, şair olmuştur. Şairlik olmasa, sevişmek, evlenmek, aile kurmak, üremek de olmazdı. Şiir, varlık bulmak, doğmaktır.

Bir mucizeyi akla getiriyorum şimdi. Suriye, Lübnan taraflarına seyahat için gurup topluyorlar. Gitmek istedim. Göndermeyeceklerini seziyorum. KGB ve SSCB Komünist Partisi Bölge Komitesi Kuruluna gittim. Onlar benim ilk saf, sade kitabımı karıştırıp şaşırıp kalırcasına hareketlerde bulundurlar.

- Ay yay yay! Giriş sözünü Hesen Tufan bizzat yazmış ha, vay!

(Hesen Tufan'ı dile almaları beni şüphelendirmek içindi aslında. Hayır, gençliğin kulağı iyi duymuyor...). Bir süre sonra şöyle dediler:

- Mayakovski kendi şiirleriyle SSSR'yi kurmaya yardım etti. Yevtuşenko Bratsk GES' ${ }^{8}{ }^{8}$ kurdu!

\footnotetext{
${ }^{8}$ Yevgeni Yevtuşenko'nun SSCB'ye 1şık sağlayan bir elektrik santralinin kurulduğu Sibirya simgesiyle Rusya tarihi boyunca bir sürgün yeri sayllan Sibirya simgesini karşılaştırdığı son derece coşkulu bir dizi şiirden oluşan yapitının adi.
} 
Fakat nerede senin böyle manzumelerin?

Kimlerle konuştuğumu tahmin etmeden şöyle cevap verdim:

- KAMAZ ${ }^{9}$ kurmaya gelen delikanlı ile kızı âşı edermiş, ben dört satırlık şiirimle de memnun olacağım. Demek ki, ben de büyük tesisi kurdum!

\section{Çılgınlık!}

Böylece ben kendim için yabancı ülkelere giden kapıları kilitledim. Açılmaz hâle getirip. "Bu yıllarda vuruldum, altın yıllarımı yaktılar!" diye sızlanmam değil bu. Saf edebiyatın yolunu şimdi pazar denilen gudubet daha da güçlü kapattı.

Hafızalarınızdaysa, Fransa Cumhurbaşkanı François Mitterrand ile bizim Gorbaçev'in ilgi çekici konuşmasını televizyondan göstermişlerdi. Zavallı doğru dürüst dinlememişiz. Gorbaçev fazla böbürlenip şöyle dedi:

- Biz pazar ilişkilerini yürüttük!

Mitterrand mütevazı bir şekilde söyledi:

- Fakat biz planlı ekonomi hakkında ümitleniyoruz...

Pazar ekonomisini kılavuz eden büyük ülkeler insanlığa layık iş veremedi. Satılık sözlerden şiir yazılmaz.

Fakat bizim edebiyatımızı da hizmetçi olmayı öğretip hazırladılar. Hizmetçiye sahip gerek. Ama kanatlı ata, düldüle sahip olmakla onun kanatlarını kırıp, boyunluk giydirecek, sırtına eyer bırakacak. Dal kuru bozkırda üremez. Sonsuz kumlukta ceviz ağacı büyümez.

İmparatorluk kendisi kadar büyük edebiyat veremiyor. Bir ceviz ağacında çok özel yirmi gövde yetişir. Geri kalanı, yeni çalıya ayrılır. Diğer büyüyen çalıda ceviz olmaz. Milletler, annemiz tabiatın çeşitli ağaçları, ayrı ayrı çalıları.

Bunu hiçbir Miçurin ${ }^{10}$ de değiştiremez. Sağ kavak ağacı hışırdar. Ihlamur ağacı, âşıklar gibi naz edip sessizce konuşur. Meşe ağacı tarihin kendi gibi derinden, yerin yüreğinden gürler. Çalılar çok ses çıkararak ufuk tarafina atılır.

\footnotetext{
${ }^{9}$ Rusya'nın otomobil üreticisi, Rusya ve Bağımsız Devletler Topluluğu'nun en büyük ağır kamyon, traktör, dizel motor ve parçaları üreten işletmesi.

10 İvan Miçurin. Rus tarım uzmanı. Mendel'in kalıtım yasalarına karşı çıkarak, kalıtsal özelliklerin belirlenmesinde çevrenin etkisine ve kazanılmış özelliklerin aktarımına ağırlık tanıyan bir kuram geliştirmiştir.
} 
Sadece yazılan şiirlerimizi, resimlerimizi, türkülerimizi, danslarımızı alıp bakınız. Kafkas halkı sıcak kaya taşına basıp tabanı pişip ütülenmiş gibi, uça uça dans eder. Başkurt ufuğun tarafina çıkar gibi olup atılır. Mari kendisinin sık ormanında yosun çileği toplamış gibi ayaklarıyla yere vurur. Fakat Tatar dansında büyük zafer karşısındaki korkaklık var. Çekinerek, uçar uçmaz, duyar duymaz dans eder.

İnancım tam, özgür Bulgar ${ }^{11}$ halkı böyle dans etmemiştir!

Fakat bugünkü danslarımıza bakıldığında sızlanırım, kulluk danslar1...

Aslında, aynı "Sık orman"daki gibi için için sızlanma sesi değil mi ki bu? Sadece sanat adamları özgür olan halk gerçek manasıyla özgür olabilir. "Derin” fikirler çok olur, özgür fikir gereklidir.

Ne zaman türkü söyleyesi gelir? Elbette, baharda dağın tepesine çıkıp yüksekten dünyaya göz atınca! Tanrı'nın kendisine yaklaşma alameti mi ki bu? Düşen her söz de alçalır... Jeolojik derinlik de bizim halk türkülerine özgü. "Madenci türküsü”, ne alamettir, hiçbir halkta da yok böylesi. Tatar işçilerinin kaderi... Onlar türkülerindeki ironiyi, kederli mizahı, üzüntü ve özlemi hangi eserlerde bulabilirdi acaba? Şerif Kemal'de vardır sadece...

Tatar şiirinin kaderi işte bu derin maden ocağında en diplere düşüp kök salmış. Moskova'da benimle birlikte okuyan Rus nesir yazarı Pletnev, ömür boyu maden işçisi, şöyle deyip ofladı:

- Zulfat, kardeşim! Bizim orada, yer altında, kör fare gibi kazdığımız boşlukta sırtlarımıza kimler binip atlamış! Kömür madeninde benim Tatar ile Rus'tan başka gördüğüm yok!

İşte sana "Maden ezgisi”, işçilik, "Sık Orman”... Tok ülkelerin tok şiir sanatına katılmak bize uygun değil. Aç gibi davranan tok hâli bize anlaşılmaz. Dünya'da Puşkin'in "Yevgeni”, Tukay'ın "Patates Şarkısı” var. kader.

Gerçek şiir geğirmeden değil, “Of, Allah!”tan başlar. O, acı

\footnotetext{
${ }^{11}$ İdil Bulgarları 7-10. yüzyılları arasında ortaya çıkan bir Türk topluluğudur. Büyük Bulgarya Hanlığı' nın Hazarlar tarafından dağıtılıp, Ön Bulgarlar halkının bölünmesinden sonra meydana gelmiş ve 13. yüzyıla kadar toplu hâlde kalmışlardır.
} 
Doğulan yerin büyüklerin ismine dair olması herkesin de gönlüne hoş gelir. Gerçi bırakıp gitmiş olsa da, "Bu yoldan o geçmiş!" deyip gururlanırız. $\mathrm{Bu}$, her yerde böyle. Fakat büyük şair Marina Tsvetayeva'nın Tataristan'a ait günleri hakkında acıyıp sızlanıp titrercesine söylemek mümkün. Bu günler, Shakespeare kalemine layık trajedinin ruh üşüten sonu. Hayır, bu facia için Tataristan'ın da halkımızın da damla kadar suçu yok. Büyük şaire ömrünce dünya boyunca altını üstüne getirip gezdiren kader cevval ve belalı bu şahıs için Alabuga'nın tenha ülkesinde ilmik hazırlamış. Onun sanatı, içinde kuş öten sözlere dönüşen facialı müzik. Onu anlamak için, duymak için sadece dünyanın gündelik ölçütlerinde kalmak yetmez.

Vahşilikten çıkıp Tanrı'ya yüz çeviren cemiyette insanoğulları bunun gibi yüksek sanatın değerini bilmeye başladı. İşte bu çağda şiir sanatının asıl saati çalacak. Sadece ne yazık ki bizde şimdiye kadar olan şiir sanatı endişesi değil... Aslında, yeryüzünün koynundaki altın parçalarının hiçbir yere acelesi yok. Onların rengi solmuyor ama değeri artıyor.

Tanrı'nın izniyle Marina Tsvetayeva'nın kabrine taş koymak nasip oldu bana. Onun kaybolduktan sonra bulunan kabri üstünde kaderler hakkında çok uzun süre düşünüp durdum.

Yürek sızısı satılmaz. Onun fiyatı yok. İnsanoğullarının parlamentosuz kabul ettiği tek anayasası, şiir sanatı. Tarihin şiirli varyantını öğrenmek, öğrenmeyi istemek felaketleri getirir.

Kardeşliğin kalp atışı, şiir. Lev Tolstoy’un kabri yanındaki ağaçtan dökülen yaprakları Möslim'in Yana Seyit köyü yanından akan sessiz sel çukuruna, Korgıldı'ya alıp boşalttım. Kalanları Tukay kabrine götürüp bıraktım. Lermontov toprağını annemin kabrine serptim. Kopernik'in doğum yerine Tukay toprağını ekledim. Kendimin bu Mecusiliğinden gönlüm hoşlandı.

"Bismillah, deyip başladım bu şiirin başlarına" şiirler işte böyle başladı. Şiir sanatı, dua. Şiir sanatı, doğrudan doğruya Allahü Teala’ya müracaat.

Şiir güçlünün elinde kırbaç olacağına, biçarenin kirpiğinde damla olsun. Siyasetçiler, eğer namusları varsa, şairlerin şiirlerinden program yapsınlar, kanun yazsınlar. Gerçek şiir sadece oyun ya da koyun (kucak) değil. Şiir, nazlı beşik de, düşman atının sırtına koyulan eyer de. Gönül sık ormanından kopup ayrılan yaban şiirimi birinin aklına inanıp göğüs doldurup okuyabilir miyim? Fakat çok okuyası gelir, dinletesi gelir. Şiir, sık ormandan yankılanan bülbül sesi. Çok gerekli değil. Onun ne zaman öttüğünü bil de tandaki çimenliğe sırtüstü yatıp 
bin yıl yaşamış meşe ağacına başını koyup sabahki pembe bulutlara baka baka dinle de dinle...

Şiir yazmak için gönlün taşarak dolması, son damlanın taşması gerek. Mordva tarafindaki Ruzayevka istasyonundan uzakta olmayan bir köyde Şerif Kamal'ın doğduğu köy Peşle'de yaşanan bir olay uzun yıllar boyunca hep içimi sızlatıp durdu.

Şairi kader durmadan izlemiş. Uzun yıllar geçse de sürüp giderek, karşısına çıkıp dururmuş. Şiir, kader.

Sözümü bitirirken, size şiirler okutasım gelir. Sadece şair hakkında değil o. O, şair kaderi, şiir kaderi hakkında. Yazılma tarihi, şiirlerin özünde.

1992

\section{KAYNAKÇA ${ }^{12}$}

Başlangıçtan günümüze Türkiye dışındaki Türk edebiyatları antolojisi C. XIX (2001). Ankara: T.C. Kültür Bakanlığı.

Davutov, R. N. (1986). Sovet Tatarstanı yazuvçıları. Kazan: Tatarstan Kitap Neşriyatı.

Maşkaraoğlu, S. (2012). Tatar şairi Zölfet'in şiirleri üzerine bir dil incelemesi (giriş, metin, dizin). Basılmamış yüksek lisans tezi, Ege Üniversitesi Sosyal Bilimler Enstitüsü, İzmir.

Öner, M. (2008). Tatar şiir okumaları: Zölfet ve "yolunu kaybeden bulut”. Türk Dünyası Dil ve Edebiyat Dergisi. 26, 49-59.

Zölfet (1995). İkě urman arası. ěssě, şiġırler, ctrlar, poemalar. Kazan: Tatarstan Kitap Neşriyatı.

Zölfet (2007). Dölfet Gosman ulı Malikov. Kazan Utları. 6, 192.

\footnotetext{
${ }^{12}$ Bu bölümdeki kaynaklar, eseri Türkçeye aktarana aittir.
} 